\title{
The Odonata of Kosrae, Eastern Caroline Islands, Micronesia ${ }^{1}$
}

\author{
Donald W. Buden ${ }^{2,4}$ and Dennis R. Paulson ${ }^{3}$
}

\begin{abstract}
A recent collection of 69 specimens together with survey counts and incidental observations during June-July 2002 provide new information on the odonate fauna of Kosrae, Micronesia. The fauna comprises one zygopteran (Ischnura aurora) and six anisopterans. It appears to have remained stable with no known extinctions or colonizations over the past half century. The fauna is nearly a subset of that of Pohnpei and the islands to the west, and it comprises six widespread weedy species and one endemic, Hemicordulia erico. Upland aquatic habitats appear largely unexploited or underutilized by odonates, and the absence of any Teinobasis species on Kosrae is in marked contrast to the presence of six species on the nearest high island, Pohnpei.
\end{abstract}

The odonate fauna of the Federated States of Micronesia (FSM) has been largely unstudied since Lieftinck's (1962) comprehensive review of populations in greater $\mathrm{Mi}$ cronesia, including Palau, the Marianas, and the Marshall Islands. In the only other studies of Odonata in the FSM, Schreiner and Nafus (1989) commented briefly on species they encountered during surveys of aquatic insects on Yap in September 1988, and Paulson (2003) and Paulson and Buden (2003) reviewed the status of populations on Pohnpei based largely on collections and observations during 2001-2002. The study reported here is an extension of these more recent investigations and focuses on Kosrae, the easternmost island in the FSM.

\section{Summary of Odonate Studies on Kosrae}

Lieftinck (1962) recorded seven species of odonates on Kosrae, including one damselfly (Zygoptera) and six dragonflies (Anisoptera).

${ }^{1}$ Manuscript accepted 19 February 2003.

2 Division of Science and Mathematics, College of Micronesia-FSM, P.O. Box 159, Kolonia, Pohnpei FM 96941 (E-mail: don_buden@comfsm.fm).

${ }^{3}$ Slater Museum of Natural History, University of Puget Sound, Tacoma, Washington 98416 (E-mail: dpaulson@ups.edu).

4 Corresponding author.

Pacific Science (2003), vol. 57, no. 4:399-407

(C) 2003 by University of Hawai'i Press

All rights reserved
The specimens he examined were obtained by three collectors ( $T$. Esaki, December 1937; R. P. Owen, July 1949; J. F. Gates Clarke, January-April 1953) and from eight localities, at least seven of which are in the lowlands (highest recorded elevation $60 \mathrm{~m}$ ), with the elevation of Clarke's "Mt. Matante" locality unstated. There are no indications that any of these specimens or any records that Lieftinck (1962) gleaned from the literature are from the uplands, which appear to have been largely or entirely overlooked during previous odonate surveys. Clarke, however, collected insects other than odonates at numerous inland stations, including the highest summits and ridges (Clarke 1953, 1976, Gressitt 1954). Clarke (1953) reported nine (unidentified) species of odonates among 704 insect species in his preliminary assessment of specimens collected on Kosrae for the Insects of Micronesia project. Whether all of the specimens of two species of odonates were lost or otherwise unavailable to Lieftinck (1962), who recorded only seven, or whether Clarke's original tally was in error is unknown.

The Owen collection appears to consist of only a few specimens from Lelu Island, and Esaki's specimens are from several widely distributed coastal or lowland localities. Most of the specimens collected by Esaki were deposited in the Kyusyu Imperial University (Japan) and unavailable to Lieftinck (1962), but locality records for the Anisoptera were included in Asahina's (1940) study. 
The study reported here provides new information on the distribution, habitat preferences, and relative abundance of odonates on Kosrae and is based largely on specimens collected and observations recorded by D.W.B. from throughout the island during 20 June-6 July 2002.

\section{Study Area}

Kosrae $\left(5^{\circ} 19^{\prime} \mathrm{N}, 163^{\circ} \mathrm{E}\right)$ is a densely forested and ruggedly mountainous, $109-\mathrm{km}^{2}$ volcanic island (about 1.2-2.6 million yr old [Keating et al. 1984]) in the eastern Caroline Islands (Figure 1). It is the easternmost state in the Federated States of Micronesia, which includes also Yap, Chuuk (formerly Truk), and Pohnpei states. Mountains compose about $70 \%$ of the island area (Whitesell et al. 1986), with maximum elevations of $630 \mathrm{~m}$ on
Mt. Finkol (=Mt. Crozer) near the center of the island, and $589 \mathrm{~m}$ on Mt. Mutunte (=Mt. Bauche), whose slopes comprise much of the north end.

The average annual rainfall is about $5000-$ $6000 \mathrm{~mm} / \mathrm{yr}$ (Merlin et al. 1993), with estimates for the mountains ranging to as high as $7500 \mathrm{~mm}$ (Whitesell et al. 1986). The average annual temperature is $27^{\circ} \mathrm{C}$ at sea level and slightly lower at higher elevations, and the difference between the average monthly minimum and average monthly maximum is less than $8^{\circ} \mathrm{C}$ throughout the year (Whitesell et al. 1986). The abundant and evenly distributed rainfall feeds at least 22 perennial streams (T.T.P.I. Office of Planning and Statistics 1979) and, together with warm year-round temperatures, contributes to the growth of lush, tropical vegetation.

Cloud forest consisting of a luxuriant as-

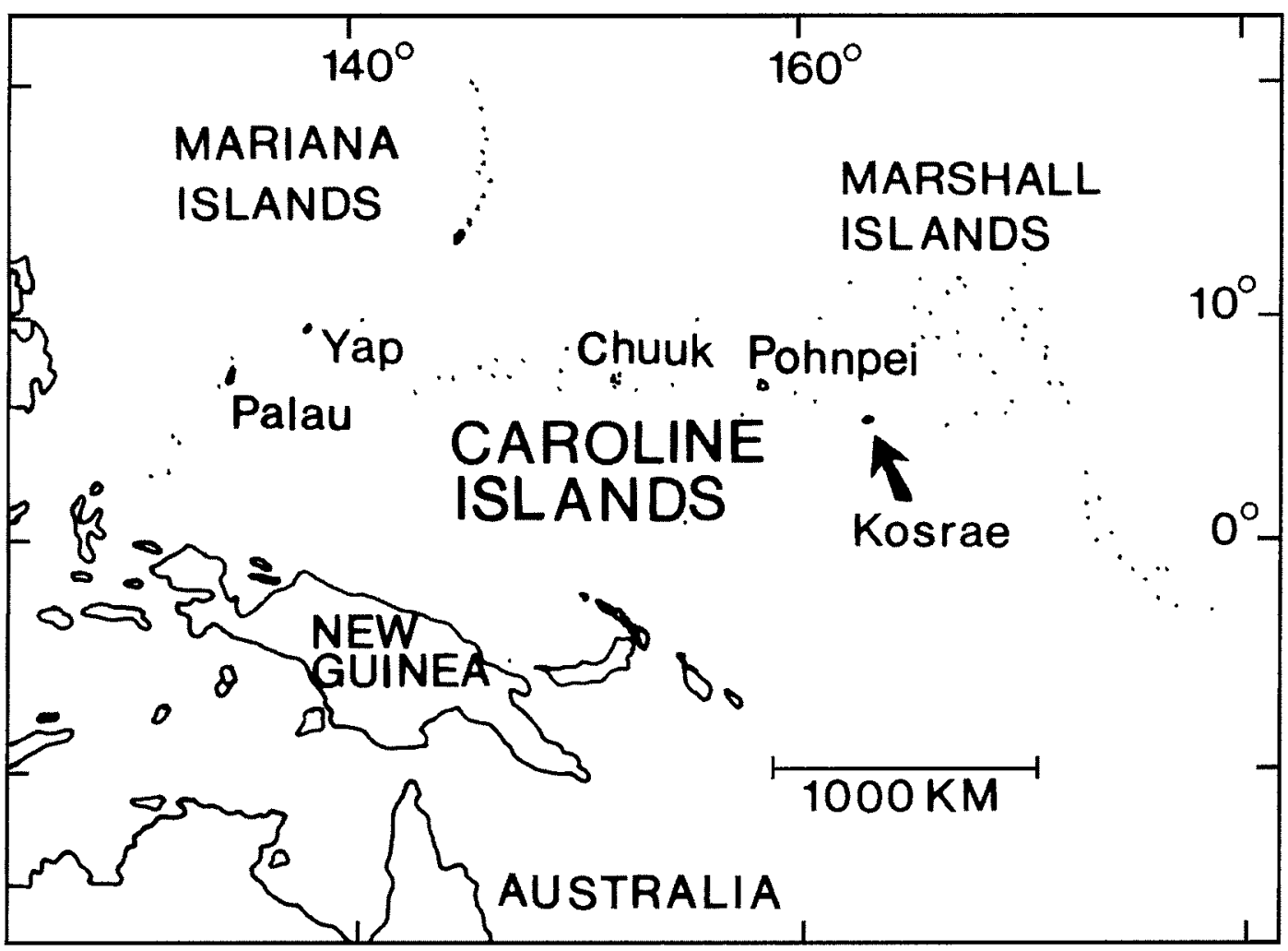

Figure 1. Location map of Kosrae and surrounding western Pacific islands. 
semblage of terrestrial and epiphytic bryophytes, ferns, and orchids and gnarled, stunted trees (5-6 m tall) and shrubs occurs on the highest peaks and ridges above about $480 \mathrm{~m}$ (Hosokowa 1952). It "represents the lowest elevation in the world at which TMCF [tropical montane cloud forest] is known to occur" (Merlin and Juvik 1993:153). Common trees and shrubs in this zone include Astronidium kusaianum, Campnosperma brevipetiolata, Cinnamomum carolinense, Elaeocarpus carolinensis, Polyscias subcapitata, and Psycbotria sp. Tree ferns (Cyatbea) are common and Dicranopteris ferns predominate in scattered open areas. Many of the tree species occur also at lower elevations where they grow to greater size. Summit areas are usually open with scattered shrubs and small trees and a dense cover of ferns and grasses. The total area of cloud forest is about 69 ha and comprises $0.6 \%$ of the total area of the island.

Rain forest, with the largest trees $25-30 \mathrm{~m}$ tall, covers most of the slopes below the cloud forest. Campnosperma brevipetiolata, Elaeocarpus carolinense, Horsfieldia nunu, Parinarium laurina, and Ficus spp. are among the dominant species; Ptychosperma ledermanniana is the only indigenous palm. Tree ferns and other ferns are common throughout. The upland forest (excluding cloud forest) covered 5090 ha $(45.5 \%$ of total area) in 1983 (Whitesell et al. 1986), but this figure has likely diminished in recent years following anthropogenic changes, such as agricultural expansion and encroachment into higher elevations and clearing land to otherwise accommodate a growing human population (Raynor 1993, Allen et al. 2001).

Agroforest is widespread in the lowlands and lower mountain slopes, where native vegetation is partially cleared for cultivation of subsistence and cash crops, including bananas (Musa spp.), breadfruit (Artocarpus altilis), betel palm (Areca catecbu), coconut (Cocos nucifera), oranges and tangerines (Citrus spp.), papaya (Carica papaya), tapioca (Manibot esculenta), taro (Alocasia, Colocasia, Cyrtosperma), and yams (Dioscorea spp.). Whitesell et al. (1986) recorded 2585 ha of agroforest in 1983 (23.1\% of total area), compared with 1844 ha $(16.5 \%)$ in 1975.
Other major lowland habitats assessed by Whitesell et al. (1986) include secondary vegetation (1272 ha $=11.4 \%$ of total area) and mangrove forests $(1562 \mathrm{ha}=14 \%)$. Freshwater swamps, with Terminalia carolinensis as the dominant tree, occur in depressions or poorly drained soils, usually behind beach strand. Terminalia swamps account for only 345 ha $(3 \%)$ of the land area, but they are considered "the most well developed, scientifically acclaimed swamp forests in all of Micronesia today" (Merlin et al. 1993:40). Other aquatic habitats widely distributed throughout Kosrae include numerous streams and seepage areas in the uplands, and streams, taro patches, roadside puddles, drainage ditches, and open cisterns in the lowlands.

Initial colonization of Kosrae by aboriginals, probably from Melanesia, occurred about 2000 B.P. (Athens 1995), and first contact with Europeans was in 1824 during a 10-day visit by the French research vessel la Coquille (Ritter and Ritter 1982). The most recent (1994) census recorded 7317 people residing mainly in several coastal settlements distributed around the entire island (Kosrae Branch Statistics Office 2000); the mountainous interior is uninhabited. A perimeter road connects nearly all the settlements; the Utwa to Walung section is still unpaved and in large part unimproved, and the Walung to Okat segment is still in the proposed and planning stages.

\section{MATERIALS AND METHODS}

All odonates encountered above $200 \mathrm{~m}$ during this survey were collected whenever possible, though difficult terrain kept success rate low. Collections at lower elevations were more selective, often bypassing the more common species to search for those less common. Terms of abundance used in species accounts are appraisals based on individuals observed during timed counts as well as impressions based on incidental observations throughout the study period: very common (50 or more encounters per day on most days under suitable viewing conditions and in suitable habitat), common (25-50 encounters per day on most days), fairly common (10-25 
encounters on most days), and uncommon (up to about 10 encounters per day, but unrecorded on many days).

Six timed survey counts were conducted in the lowlands (below $200 \mathrm{~m}$ ) along paved and unpaved roads and recently cleared areas, mainly along the completed and partially completed parts of the circumferential road, and through a wide variety of habitats. Surveys totaled $14.3 \mathrm{hr}$ at different times of the day and covered all areas of the island perimeter with the exception of the northern and northeastern sections. Counts are presented as encounters per hour and give a crude approximation of the relative abundance of species in edge habitats throughout the lowlands.

All specimens are currently in the collection of D.R.P. but are to be transferred to the International Odonata Research Institute, Gainesville, Florida.

\section{SPECIES ACCOUNTS}

\section{Family Coenagrionidae}

\section{Iscbnura aurora (Brauer)}

This species occurs widely from India and Sri Lanka to Polynesia and New Zealand (Steinmann 1997), and Lieftinck (1962) listed numerous localities from throughout Micronesia. Lieftinck (1962) recorded an unstated number of $I$. aurora collected by Esaki, Owen, and Clarke on Kosrae in the lowlands (Lelu Island, Malem, Mwot-Utwe, and Mutunlik) during December-February, April, and July. This species was encountered only occasionally during the June/July 2002 survey, and mainly in wet, lowland marshy areas, including grassy, weedy drainage ditches and taro patches. It was locally very common in some areas $\left(3-4 \mathrm{~m}^{2}\right)$, but scarce in similar habitats elsewhere. It was found mainly at or near sea level but occasionally along stream banks to elevations as high as $182 \mathrm{~m}$.

\section{Family Aeschnidae}

\section{Anax guttatus (Burmeister)}

This species is widespread in the Pacific islands through Indo-Australia to Southeast Asia, India, and the Seychelle Islands (Stein- mann 1997). The only previous records of $A$. guttatus on Kosrae are a male collected by Clarke at Mutunlik in February 1953, and one or more specimens collected by Owen on Lelu Island in July 1949 (Lieftinck 1962). During the June/July 2002 survey, A. guttatus was uncommon to locally fairly common in open, sparsely vegetated areas; it was most numerous along roads, over parking lots and fields, and in recently cleared areas. It was often found near standing water; some were observed patrolling over freshwater swamps.

\section{Family Cordulitdae}

\section{Hemicordulia erico Asahina}

The genus Hemicordulia is widespread in Oceania, but it is represented on many islands and small island groups by endemic species. Asahina (1940) described H. erico endemic to Kosrae from a series of 11 males and one female collected by Esaki in 1937. He (Asahina 1940 ) recorded all 12 in "materials examined" as collected in November, but where he listed them as holotype, allotype, and 10 paratypes, he reported the collection date of the holotype (a male from Malem) as 22 December. Asahina's "materials examined" section includes a male from Malem collected on 22 November, but December is probably the correct month for this entire series, because all the other of Esaki's Kosraean records annotated as to date by Asahina (1940), and involving three other species, range from 1 to 18 December. Furthermore, other locality records throughout Asahina's text indicate that Esaki was elsewhere in Micronesia on some of the November dates in question. Consequently, the collection date of the paratype from Mwot-Utwe that Lieftinck (1962) reported as 8 November 1939 should be emended to 8 December 1937.

In addition to the paratype, Lieftinck (1962) examined six males and one female collected by Clarke during February (5 specimens), March (1), and April (1) 1953 and another male collected by Owen in July 1949. Clarke's material included a pair in copula at Funaunpes in February. With the possible exception of Clarke's specimen from an unspecified elevation on Mt. Mutunte, all of 
these early records are from the lowlands. The locality for Owen's specimen was unstated, but all of his other records are from Lelu Island, so his specimen of $H$. erico probably is from there as well.

During the June/July 2002 survey, H. erico was encountered throughout the island from sea level to the summits of the highest peaks. It was most numerous along the circumferential road passing through secondary woodland, agroforest, and swampland in the northwestern quadrant, between the Okat River bridge and the causeway to the airport (33 total, 19 per hour, 29 June), but it was scarce to uncommon in similar habitats along the road on the eastern side of the island, where only 5-6 were seen throughout the study period. It was the most frequently encountered odonate in the higher elevations (Table 1), especially on the fern-, shrub-, and grass-covered summits. Four or five were observed together patrolling an area of several square meters on the slope of Mt. Oma, just below the summit at about $440 \mathrm{~m}$ elevation on 28 June.

One female with eggs extruding from the abdomen collected in Walung Village on the southwestern coast on 3 July was the only direct evidence of breeding. However, males were seen patrolling over both the Malem and Finkol Rivers, which may have been breeding habitat. The closely related $H$. baluco Asahina was similarly common at all elevations on Pohnpei, but its breeding habitat was not determined certainly (Paulson and Buden 2003).

Asahina (1940) was unable to describe the female cerci in this species. They are cylindrical, very slightly upcurved, thickest at midlength, bluntly pointed, and $2.5 \mathrm{~mm}$ in length. Those of its congener from Pohnpei, $H$. baluco Asahina, are similar but straight and just over $3 \mathrm{~mm}$ in length.

With the almost simultaneous collection of large series of $H$. erico and $H$. baluco (Paulson and Buden 2003), a comparison between these two species is warranted. Hemicordulia erico is slightly smaller than $H$. baluco, with a distinctly shorter abdomen. Mean hind wing length of males is $26.6 \mathrm{~mm}(24.5-29, n=28)$ in $H$. erico versus $28.2 \mathrm{~mm}(27-29.5, n=37)$ in $H$. baluco, and mean hind wing length of females is $29.1 \mathrm{~mm}(28-29.5, n=7)$ in $H$. erico versus $29.9(29.5-31.5, n=11)$ in $H$. baluco. Mean abdomen length of males is $28.6 \mathrm{~mm}(25-31, n=26)$ in $H$. erico versus $32.6 \mathrm{~mm}(30-35, n=18)$ in $H$. baluco, and mean abdomen length of females is $29.1 \mathrm{~mm}$ $(28-29.5, n=7)$ in $H$. erico versus $36.4 \mathrm{~mm}$ $(36-37, n=6)$ in H. baluco.

Asahina (1940:8) said of this species, "colour very dull greenish (more shining in one

TABLE 1

Distribution of Odonates Collected on Kosrae during 20 June-6 July 2002, with Encounter Rates ${ }^{\prime}$ during Lowland Surveys

\begin{tabular}{|c|c|c|c|}
\hline \multirow[b]{2}{*}{ Species } & \multicolumn{2}{|c|}{ Specimens Collected ${ }^{b}$} & \multirow[b]{2}{*}{ Sightings/hr } \\
\hline & Below $200 \mathrm{~m}$ & Above $200 \mathrm{~m}$ & \\
\hline \multicolumn{4}{|l|}{ Zygoptera } \\
\hline Iscbnura antora & $3 \mathrm{M}, 1 \mathrm{~F}$ & & 1.0 \\
\hline \multicolumn{4}{|l|}{ Anisoptera } \\
\hline Anax guttatus & $1 M$ & & 1.0 \\
\hline Hemicordulia erico & $14 \mathrm{M}, 1 \mathrm{~F}$ & $14 \mathrm{M}, 6 \mathrm{~F}$ & 4.0 \\
\hline Diplacodes bipunctata & $5 M, 1 F$ & & 2.6 \\
\hline Pantala flavescens & $6 \mathrm{M}, 2 \mathrm{~F}$ & & 3.8 \\
\hline Tholymis tillarga & $7 \mathrm{M}, 2 \mathrm{~F}$ & $1 F$ & 7.0 \\
\hline Tramea transmarina & $3 \mathrm{M}, 1 \mathrm{~F}$ & $1 F$ & 0.8 \\
\hline
\end{tabular}

a Calculated as the average number of individuals encountered on six timed roadside counts totaling $14.3 \mathrm{hr}$ at different times of the day from 0720 to 1520 hours during 20 June-6 July 2002: eastern section (between Tofol and Malem Village, 6.0 hr), southwestern section (between Utwa and Walung Villages, $6.5 \mathrm{hr}$ ), northwestern section (between Okat River bridge and airport causeway, $1.8 \mathrm{hr}$ ).

" $M$, males; $F$, females. 
specimen)." In fact, $H$. erico is not at all dull but has a glittering metallic thorax much like that of $H$. baluco, but it is an overall darker species. The thorax in mature male $H$. erico is entirely metallic green on top and sides; that of male $H$. baluco is the same color but with the nonmetallic orange brown of the ventral surface penetrating diffusely up the sides. Female $H$. erico are colored as males, but female $H$. baluco are even less brightly colored than the males, with the metallic green on the thorax restricted to the upper parts of the mesepisternum and isolated stripes the length of the mesepimeron and metepimeron. Additional differences are seen in the hind femora (black in $H$. erico, mostly orange brown in $H$. baluco) and abdominal segment 10 and its cerci (black in H. erico, brown in $H$. baluco).

In both species, the wings of immature males are completely hyaline, and those of immature females have an orange wash over the base of both wings not quite reaching the subtriangle in the forewings and the triangle in the hind wings. In $H$. erico, the wings of most mature males become washed with dusky brown, but in $H$. baluco relatively few males are so colored (difficult to quantify). In mature females, the wings are similarly almost entirely dusky in $H$. erico, but in $H$. baluco the dusky washes are restricted to the postnodal areas of all wings and another diffuse area from the distal end of the anal loop back to the wing margin; the base remains orange in all females.

\section{Family Libellulidae}

\section{Diplacodes bipunctata (Brauer)}

This species ranges widely in Australasia and East Asia (Steinmann 1997), and Lieftinck (1962) listed numerous locality records from throughout Micronesia. Asahina (1940) recorded five males and three females collected by Esaki on Kosrae during 1-14 December 1937. At least one other specimen recorded by Lieftinck (1962) as collected at Mutunlik in February 1952 probably is a part of Clarke's 1953 collection and should be included with his January and February (1953) records; the number of specimens was left unstated. This species was fairly common in low, open, sparsely vegetated areas during the June/July 2002 survey. It was most numerous in the vicinity of rain-filled ruts on dirt and gravel roads and road construction sites. One pair was collected in tandem ovipositing in a roadside puddle at Saulung at the southern end of the island on 1 July 2002.

\section{Pantala flavescens (Fabricius)}

This nearly cosmopolitan species ranges throughout the Tropics and subtropics worldwide (Steinmann 1997). Lieftinck (1962:85) indicated that Clarke encountered $P$. flavescens at Mutunlik, Kosrae, in February 1953 but did not list specimens and did not annotate records for any Micronesian islands, stating only that there were "Many Micronesian specimens, collected on almost all island groups; data not all recorded." This species was uncommon to locally common throughout the lowlands on Kosrae during the June/July 2002 survey. It was most numerous over roadways and along roadsides. One pair oviposited in tandem on the rainwet cement surface of a basketball court, and another was in copula over a roadside puddle; both pairs were collected in Utwa Village on 1 July 2002, and both of the females have eggs extruding from the abdomen.

\section{Tholymis tillarga (Fabricius)}

This species ranges from Africa eastward across southern Asia and to Australia and Oceania (Lieftinck 1962). The only previous records from Kosrae are the eight males and four females collected by Esaki during 3-18 December 1937 (Asahina 1940). Tholymis tillarga was the most common odonate encountered on Kosrae during the June/July 2002 survey. It was most numerous in coastal lowlands and was observed mainly at dusk. The greatest concentration was in the Tenwak/ Mutunlik area along the shoreline and adjacent road bank, where 300-400 were estimated in an area covering about 100 by $20 \mathrm{~m}$. Most were flying close to the ground or just above the surface of the water along the shoreline. Others were in small groups flying in tight circles near the tops of scattered roadside trees. Tholymis tillarga was the only odonate regularly encountered along rain- 
forest trails, where individuals would dislodge from understory vegetation when disturbed and fly higher into the canopy. It occurred from sea level to the mountain summits, but was less numerous at the higher elevations where water was less common.

\section{Tramea transmarina Brauer}

This species occurs widely in the IndoAustralian region and the islands of Oceania (Lieftinck 1962, Steinmann 1997). Asahina (1940) recorded three T. limbata (=transmarina) collected by Esaki at MwotUtwe on 8 December 1937, and Lieftinck (1962) recorded five collected by Clarke at Mutunlik during February-March 1953 and another by Owen at Lelu Island in July 1949; all nine were males. Lieftinck (1962) included Kosrae and other eastern Micronesian islands within the range of the subspecies $T . t$. propinqua Lieftinck. During the survey reported here, this species was scarce or uncommon (uplands) to occasionally fairly common (lowlands), mainly over roads and other open areas. Two or three were observed on the open summits of Mt. Mutunte on 5-6 July.

\section{DISCUSSION}

Of the seven species of Odonata known from Kosrae, Iscbnura aurora is the only zygopteran and Hemicordulia erico the only endemic species. By contrast, the adjacent island Pohnpei hosts nearly twice as many species (15), of which nearly half (7) are endemic, and $I$. aurora is only one of seven Zygoptera (Paulson and Buden 2003). The greatest disparity in the two faunas results from the presence of six species of the zygopteran genus Teinobasis on Pohnpei and none on Kosrae. The radiation of Teinobasis on Pohnpei is a unique situation in the Caroline Islands; Palau and Chuuk (=Truk) each have only one species and Yap, like Kosrae, has none. But Chuuk and Yap are relatively low islands with few freshwater streams, and Palau, though with only one Teinobasis, has a total of at least 18 odonate species. Kosrae, like Pohnpei, is a densely forested, ruggedly mountainous volcanic island with high annual rainfall and numerous mountain streams and other wetlands that would provide seemingly suitable resources for one or more Teinobasis species or an ecological equivalent. Although dragonflies and damselflies are occasionally encountered along Kosrae forest streams, this habitat appears largely unexploited or underutilized by odonates. Small island size and distance from potential sources almost certainly contribute to the depauperate fauna on Kosrae, as expected according to the MacArthur and Wilson (1967) model of island biogeography. Kosrae is about one-third the size of Pohnpei, and, excluding a scattering of low-lying atolls, it is the easternmost island in Micronesia and the most distant from potential source populations on the larger Indo-Australian land masses. Area/distance effects notwithstanding, the ecological breadth of Kosrae suggests that it could support more than the seven species of odonates it now has (Paulson and Buden 2003). The Kosrae odonate fauna appears to have remained stable with no known extinctions or colonizations during the past half century; all the species recorded by Lieftinck (1962), but no others, were observed during this study.

With the exception of the Teinobasis species complex, the odonate faunas of Pohnpei and Kosrae are very similar in species composition. Both islands have Iscbnura aurora, Anax guttatus, Diplacodes bipunctata, Tholymis tillarga, Pantala flavescens, and Tramea transmarina, all of which are widespread, weedy species common among the islands of the western Pacific and, in many cases, well beyond. Except for Hemicordulia erico, which appears closely related to the Pohnpeian endemic $H$. baluco, Kosrae has no species that does not also occur on Pohnpei. However, Pohnpei has Pacificotbemis esakii, endemic to the island at the genus level, and Agrionoptera sanguinolenta, which is also absent from Kosrae. The absence of $A$. sanguinolenta is somewhat unexpected because it is common throughout the lowlands of Pohnpei (Paulson and Buden 2003), occurs on several disparate Micronesian atolls (D.W.B., unpubl. data), and has been recorded in the Bonin Islands, Japan, about $2600 \mathrm{~km}$ north of the eastern Carolines (Karube and Sugimura 1997).

Odonates are more common in the low- 
lands than in the mountains on both Pohnpei and Kosrae, but some species found on both islands tend to extend higher up on the slopes of Kosrae. Tramea transmarina and Tholymis tillarga were encountered on the highest peaks on Kosrae, and T. tillarga was frequently flushed from trailside vegetation in low- to moderate-elevation rain forest. Neither species was observed in cloud forest on Pohnpei, and no anisopterans were regularly encountered in the forest understory there. In addition, no Iscbnura aurora was observed above $30 \mathrm{~m}$ on Pohnpei, but the species was encountered at elevations as high as $182 \mathrm{~m}$ on Kosrae. Whether such a distribution is a form of ecological release in the presence of fewer species on Kosrae requires additional study.

\section{ACKNOWLEDGMENTS}

We thank the many residents of Kosrae for their numerous kindnesses and courtesies extended to D.W.B. during the course of field investigation, and we are especially grateful to Joseph Methukulathel, biologist at College of Micronesia, Kosrae campus, for providing housing accommodations in his personal residence for the duration of the study. Madison Nena and Katrina Adams of the Kosrae Village Hotel and Simpson Abraham and staff at Kosrae Island Development Review Commission were very helpful in arranging contacts with local guides.

\section{Literature Cited}

Allen, J. A., K. C. Ewel, and J. Jack. 2001. Patterns of natural and anthropogenic disturbance of the mangroves on the Pacific Island of Kosrae. Wetlands Ecol. Manage. 9:279-289.

Asahina, S. 1940. Odonata-Anisoptera of Micronesia. Tenthredo 3:1-23.

Athens, S. J. 1995. Landscape archaeology: Prehistoric settlement, subsistence, and environment of Kosrae, Eastern Caroline Islands, Micronesia. International Archaeological Research Institute, Inc., Honolulu.

Clarke, J. F. Gates. 1953. Report on insect collecting trip to Kusaie, Caroline Islands.
Pacific Science Board. 7 pp. (mimeographed). Available at Hamilton Library, University of Hawai'i at Mānoa, Honolulu.

- 1976. Insects of Micronesia, Microlepidoptera: Tortricoidea. Insects Micronesia 9 (1): 1-144.

Gressitt, J. L. 1954. Insects of Micronesia, Introduction. Insects Micronesia 1:1-257.

Hosokowa, T. 1952. A plant sociological study in the mossy forests of Micronesian islands. Mem. Fac. Sci. Kyushu University Ser. E (Biol) 1:65-82.

Karube, H., and M. Sugimura. 1997. A new record of Agrionoptera sanguinolenta Lieftinck from Japan. Aeschna 34:1-4.

Keating, B. H., D. P. Mattey, J. Naughton, C. E. Helsley, D. Epp, A. Larawicz, and D. Schwank. 1984. Evidence for a hot spot origin of the Caroline Islands. J. Geophys. Res. 89:9937-9948.

Kosrae Branch Statistics Office. 2000. 1999 Kosrae State statistical bulletin. FSM Department of Economic Affairs, FSM National Government, Kosrae State.

Lieftinck, M. A. 1962. Insects of Micronesia, Odonata. Insects Micronesia 5:1-95.

MacArthur, R. H., and E. O. Wilson. 1967. The theory of island biogeography. Princeton University Press, Princeton, New Jersey.

Merlin, M. D., and J. O. Juvik. 1993. Montane cloud forest in the tropical Pacific: Some aspects of their floristics, biogeography, ecology, and conservation. Pages 149-162 in L. S. Hamilton, J. O. Juvik, and F. N. Scatena, eds. Tropical montane cloud forests. East-West Center, Honolulu, Hawai'i.

Merlin, M. D., R. Taulung, and J. Juvik. 1993. Plants and environments of Kosrae [Sahk kap ac kain in acn Kosrae]. EastWest Center, Honolulu, Hawai'i.

Paulson, D. R. 2003. Teinobasis budeni sp. nov. from Pohnpei, eastern Caroline Islands, Micronesia (Odonata: Coenagrionidae). Int. J. Odonatol. (in press).

Paulson, D. R., and D. W. Buden. 2003. The Odonata of Pohnpei, eastern Caroline Islands, Micronesia. Int. J. Odonatol. (in press). 
Raynor, B. 1993. Montane cloud forests in Micronesia: Status and future management. Pages 176-182 in L. S. Hamilton, J. O. Juvik, and F. N. Scatena, eds. Tropical montane cloud forests. East-West Center, Honolulu, Hawai'i.

Ritter, L. T., and P. L. Ritter (transls. and eds.). 1982. The European discovery of Kosrae Island. Micronesian Archaeological Survey Report No. 13. Historic Preservation Office, Trust Territory of the Pacific Islands, Saipan.

Schreiner, I., and D. Nafus. 1989. Insects in the freshwater environments of Yap. Pages 21-32 in S. G. Nelson, ed. The inland aquatic habitats of Yap. Univ. Guam Mar. Lab. Rep. 92.

Steinmann, H. 1997. World catalogue of Odonata. Vols. 1 and 2. Walter de Gruyer, New York.

T.T.P.I. [Trust Territory of the Pacific Islands] Office of Planning and Statistics. 1979. Kosrae land use guide. T.T.P.I. Office of Planning and Statistics, Saipan.

Whitesell, C. D., C. D. MacLean, M. C. Falanruw, T. G. Cole, and A. H. Ambacher. 1986. Vegetation survey of Kosrae, Federated States of Micronesia. U.S. Dep. Agric., For. Serv., Pac. Southwest For. Range Exp. Stn. Resour. Bull. PSW-17. 